\title{
Publisher's Note: Nonequilibrium Electron Rings for Synchrotron Radiation Production [Phys. Rev. Lett. 110, 154801 (2013)]
}

Hywel Owen, Peter H. Williams, and Scott Stevenson

(Received 12 April 2013; published 24 April 2013)

DOI: $10.1103 /$ PhysRevLett.110.179903

PACS numbers: 29.20.db, 29.20.dk, 29.27.Bd, 41.60.Ap, 99.10.Fg

This paper was published online on 9 April 2013 with errors in the text on page 3, and in the caption to Table II. On page 3, left-hand column, the fifth line of the second paragraph should read as " $\tau_{b}$ is the possible bunch spacing, i.e., $I=83 \mathrm{~mA}$ for $12 \mathrm{~ns} . . . "$. The last line of the caption to Table II should read as "cases is $83 \mathrm{~mA}$, limited by the $12 \mathrm{~ns}$ bunch spacing." The paper has been corrected as of 11 April 2013. The text is correct in the printed version of the journal.

Published by the American Physical Society under the terms of the Creative Commons Attribution 3.0 License. Further distribution of this work must maintain attribution to the author(s) and the published article's title, journal citation, and DOI. 